\title{
A PANDEMIA DE COVID-19
}

\section{UMA VISÃO MULTIDISCIPLINAR}

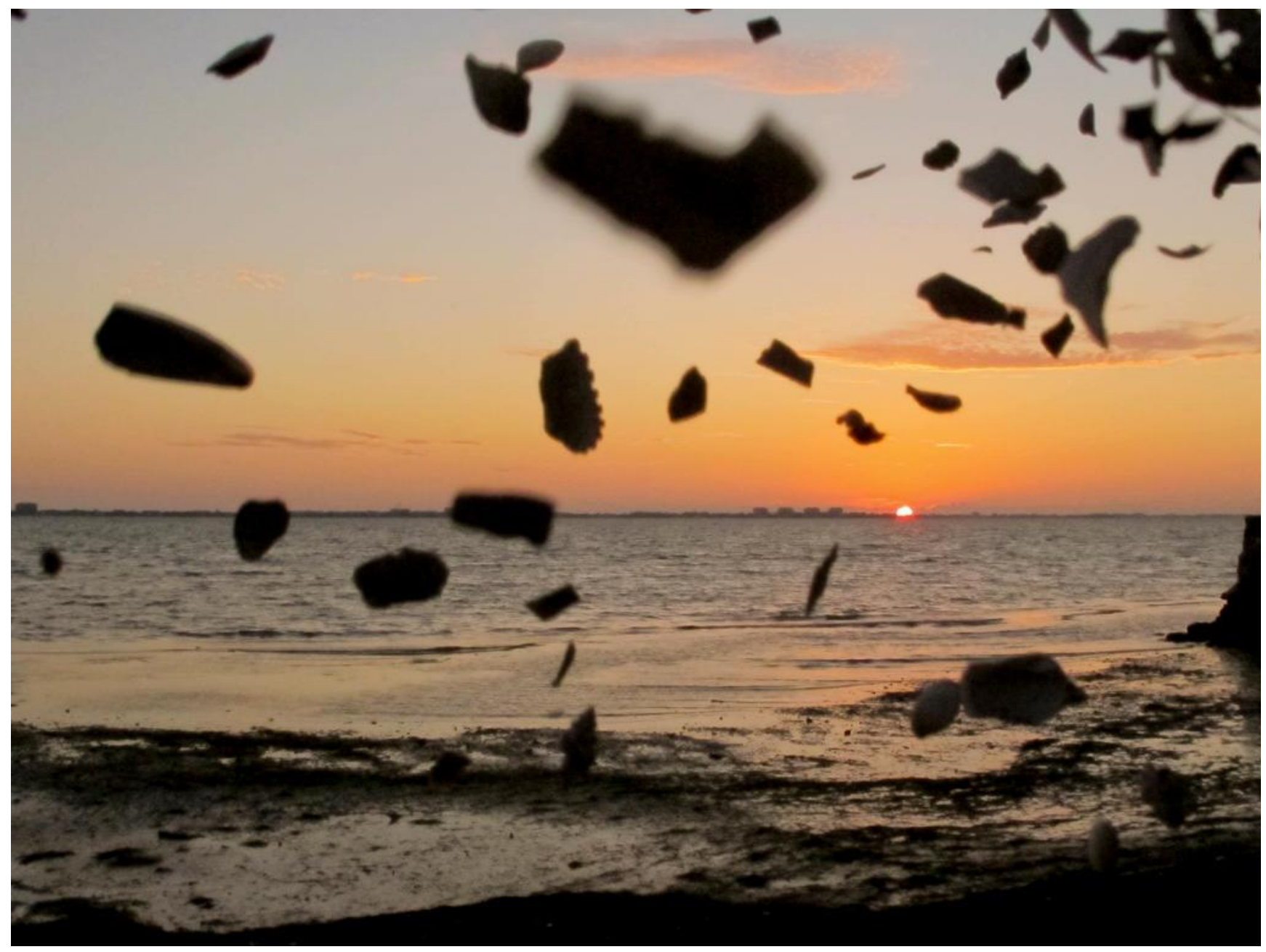

Figura 1: Sunset Deco. Crédito: Ted Weber Gola, Saratosa, 2011.

Há mais de cem anos, milhões morreram por causa da Gripe Espanhola. Com exceção de historiadores e pesquisadores - e, talvez, de alguns admiradores de literatura - quantos de nós teríamos condições de fazer qualquer reflexão, ilação ou análise a respeito dos impactos de uma pandemia para a espécie humana? Desculpamo-nos: aconteceu há muito tempo! Por isso, por conta de uma suposta novidade histórica e em função das milhares de mortes diárias, o novo coronavírus tornou-se o centro de nossas vidas desde 11 de março de 2020, quando a Organização Mundial de Saúde decretou o estado de pandemia.

Soube-se, logo no início, que a peste vinha de fora, que ela havia surgido lá longe, na Ásia. Por descuido, arrogância em desejar o controle da natureza, por conta de hábitos estranhos na alimentação e na manipulação de seres vivos em grandes mercados, ou por outros motivos obscuros que alimentaram as mais criativas teorias de conspiração, a doença havia sido trazida para os aeroportos ocidentais por passageiros de classe média e alta que voltavam do estrangeiro. 
Tal como ocorrera com a irrupção da lepra (século 12), da peste bubônica (século 14), e da varíola (séculos 5 ao 7) nas cidades medievais, as cidades modernas foram cercadas e fechadas. Ninguém entrava, ninguém saía. Os guetos improvisados tornaram todos prisioneiros, os que estavam dentro e os que estavam fora. Os guardas que vigiavam as entradas ganharam inusitado poder: eles eram os únicos que podiam permitir o reencontro de amantes, os abraços dos familiares, os gestos de solidariedade com os que padeciam da doença, da miséria e do abandono.

Os guardiões que comandavam os guardas demoraram para chegar a um acordo. Com as cidades lacradas, como fazer chegar alimentos, remédios, ajuda médica? Quais cidades deveriam ser atendidas prioritariamente? Os guardiões se isolaram: cada um percebeu que deveria cuidar de seus próprios muros, cada um deveria decidir sobre os que iam morrer e os que mereciam viver.

Alguns guardiões protestaram: para quê, afinal, fechar as cidades? Não seria melhor aguardar que morressem os mais fracos, os que tivessem que morrer, e deixar que a cidade se curasse com o passar do tempo? Defensores ideológicos da vida ou da morte, os Estados modernos desenvolveram estratégias de sobrevivência, como analisa Ayala-Colqui. Outros buscaram na Ciência os dados necessários para a tomada de decisões racionais: quais as relações entre o número de casos, de óbitos e a poluição ambiental? Essa é a reflexão realizada por Langa e colaboradores.

As escolas fecharam. Das salas, os alunos foram conduzidos a retângulos virtuais, cada qual em sua prateleira, e os professores viram-se obrigados a inventar novos jeitos de ensinar os velhos conteúdos no silêncio e na solidão do mundo escuro da tela iluminada. As escolas tiveram que reaprender, como nos mostra Alcântara, Antunes-Souza e colaboradores.

Enquanto cientistas corriam para descobrir vacinas, líderes de negócios e guardiões conflitavam sobre quem teria direito à cura, tema debatido por Acosta e colaboradores. Também negavam os benefícios no uso de máscaras para diminuir as possibilidades de contágio, àquele momento, e até agora, um eficiente instrumento preventivo, como nos explicam Rocha e colaboradores.

Boatos e rumores procuraram amainar a sede por notícias e explicações científicas: verdades foram desmentidas, mentiras transformaram-se em verdades, como nos mostra Girotto Júnior e colaboradores. Professores e pesquisadores armaram barreiras e cavaram trincheiras: como protestar diante da outra pandemia, dessa vez a de desinformação? Fazia-se necessário resistir, e ainda se faz, como Judensnaider e colaboradores sugerem e trazem para o campo do debate.

Nos meses sem fim que tem durado nossa quarentena, tivemos a oportunidade, desperdiçada, de ver como seria o mundo sem nós. Nas semanas de isolamento total, por alguns poucos dias, as ruas ficaram vazias, o ar limpo, os mares mais esverdeados e claros. Tivemos a oportunidade de perceber quão predatórios somos, quão extenuado está o nosso planeta.

Poderíamos ter ido à praia e ver o tempo se manifestar sob a forma de sombras, de folhas e de nuvens, tal como, para nós, evoca a belíssima imagem de Ted Weber Gola que abre nosso editorial. Teria sido possível pensar nossa finitude e a infinitude do mundo, cuja existência prescinde de qualquer manifestação humana. Perdemos a chance. Com sorte, talvez tenhamos outra apenas daqui a cem anos.

Ivy Judensnaider

(Universidade Paulista, Universidade Estadual de Campinas, Brasil)

ivy.naider@gmail.com

Cristina Pontes Bonfiglioli

(Pontifícia Universidade Católica de São Paulo, Universidade de São Paulo, Brasil) cristina.bonfiglioli@gmail.com 